\title{
Alchizan
}

ISSN 1907-0985, E ISSN 2442-8256

Vol. 17, No. 1, 2021, h. 115-138

DOI: https://doi.org/10.30603/am.v17i1.2070

\section{Toleransi Pelencengan Arah Kiblat di Indonesia Perspektif Ilmu Falak dan Hukum Islam}

\author{
Ismail, Dikson T. Yasin, Zulfiah
}

IAIN Lhokseumawe, IAIN Sultan Amai Gorontalo, IAIN Sultan Amai Gorontalo

Email: ismail@iainlhokseumawe.ac.id; dikson_yasin@iaingorontalo.ac.id; zulfiah@iaingorontalo.ac.id

\begin{abstract}
This study discusses the limits of deviation of the direction of qibla that is allowed in facing the direction of qibla in Indonesia. This study uses qualitative descriptive analysis with an astronomical approach and Islamic law approach. The results show that there are two types of tolerance towards the qibla, namely mathematical tolerance, and sociological tolerance. Mathematically, tolerance lies in the ability to face three directions, namely the direction of the Ka'bah, the direction of the holy mosque, and the direction of the forbidden land. Sociologically, the deflection tolerance of the direction of qibla $6^{\circ}$ bows to the left of the Ka'bah or the right of the Ka'bah. Mathematical qibla direction tolerance is provided for the construction of places of worship such as mosques and small mosques, while sociological of Islamic Law, qibla tolerance is allocated for people who perform prayers.
\end{abstract}

Keywords. Astronomy, Qibla Direction, Deviation Tolerance

\section{Tolerance of Qibla Direction in Indonesia in Islamic Astronomy and Islamic Law Perspectives}

\begin{abstract}
Abstrak: Penelitian ini membahas tentang batas pelencengan arah kiblat yang diperbolehkan dalam menghadap arah kiblat di Indonesia. Penelitian ini menggunakan analisis deskriptif kualitatif dengan pendekatan astronomis dan hukum Islam. Hasil penelitian menunjukkan bahwa ada dua macam jenis toleransi arah kiblat, yaitu toleransi secara matematis dan toleransi secara sosiologis. Secara matematis, toleransi terdapat pada kebolehan terhadap menghadap tiga arah, yaitu arah Ka'bah, arah Masjidilharam, dan arah tanah haram. Secara sosiologis, toleransi pelencengan arah kiblat $6^{\circ}$ busur ke kiri Ka'bah atau ke kanan Ka'bah. Toleransi arah kiblat matematis diperuntukkan pada pembangunan tempat ibadah seperti masjid dan mushallah, sedangkan toleransi arah kiblat secara sosiologis hukum Islam diperuntukkan bagi orang yang melaksanakan salat.
\end{abstract}

Kata Kunci: Ilmu Falak, Arah Kiblat, Toleransi Pelencengan 


\section{A. Pendahuluan}

Dinamika pergeseran arah kiblat memuncak di Indonesia pada tahun 2010, dengan isu banyak masjid dan mushallah yang tidak sesuai arah kiblat menyebabkan Majelis Ulama Indonesia (MUI) mengeluarkan fatwa tentang arah kiblat bagi masyarakat Indonesia. ${ }^{1}$ Dengan lahirnya fatwa MUI Nomor 5 Tahun 2010 tentang Arah Kiblat, menyebabkan semakin marak pengukuran ulang arah kiblat masjid dan mushalla, bahkan kuburan di Indonesia. Laporan hasil pengukuran arah kiblat di Indonesia semakin banyak dipublikasikan dengan sudut pandang dan pendekatan yang berbeda-beda. Penelitian ini bertujuan untuk merumuskan batas toleransi dalam pelencengan arah kiblat di Indonesia. Rumusan batasan toleransi terhadap pelencengan arah kiblat menjadi pengetahuan yang sangat penting bagi masyarakat akademisi dan peneliti di Indonesia dalam perumusan atau mengambil kesimpulan terhadap akurat atau melenceng sebuah bangunan masjid dengan arah kiblat. Selama ini belum ada standar baku dalam pengukuran arah kiblat yang disepakati sebagai standar toleransi pelencengan arah kiblat yang diperbolehkan di Indonesia.

Ahmad Izzuddin dalam penelitian “Typology jihatul ka'bah on qibla direction of Mosques in Semarang" menyimpulkan sebuah masjid dianggap masih akurat bila arah bangunan masjid tidak melenceng di atas $2^{\circ}$ busur dari arah Ka'bah. ${ }^{2}$ Zainul Arifin dalam penelitian "Toleransi Penyimpangan Pengukuran Arah Kiblat" menyimpulkan bahwa toleransi penyimpangan arah kiblat yang mampu diketahui dengan menggunakan instrumen theodolit adalah selama sebuah bangunan masjid masih menghadap ke Kota Makkah dengan pendekatan matematis dapat disimpulkan bahwa pelencengan $0^{\circ} 6$ ' 36" dan $-0^{\circ} 10^{\prime} 12^{\prime \prime}$ dari posisi Ka’bah merupakan batas pelencengan yang diperbolehkan dalam menghadap arah kiblat di

\footnotetext{
${ }^{1}$ Agus Yusrun Nafi', "Verifikasi Fatwa MUI Nomor 03 Tahun 2010 Tentang Arah Kiblat," Mahkamah: Jurnal Kajian Hukum Islam 9, No. 1 (26 Februari 2016), https://doi.org/10.24235/ mahkamah.v9i1.289.

${ }^{2}$ Ahmad Izzuddin, “Typology Jihatul Ka'bah on Qibla Direction of Mosques in Semarang," Ulul Albab: Jurnal Studi Dan Penelitian Hukum Islam 4, No. 1 (1 November 2020): 1-15, https://doi.org/10.30659/jua.v4i1.12186.
} 
Indonesia. ${ }^{3}$ Anisah Budiwati dan Saiful Aziz juga melaporkan hasil penelitian dengan judul "Akurasi Arah Kiblat Masjid di Ruang Publik", hasil penelitian ini menyebutkan bahwa arah kiblat masjid tergolong masih akurat karena masih menghadap ke arah Kota Makkah dengan besaran pelencengan arah kiblat yang ditemukan hanya sebesar 6 menit busur. ${ }^{4}$

Penyebab arah kiblat di Indonesia banyak yang tidak sesuai arah kiblat bisa dilihat dari beberapa hasil penelitian, diantaranya yang dilakukan oleh Rahmatiah HL $(2020)^{5}$ dengan judul "Pengaruh Human Eror Terhadap Akurasi Arah Kiblat Masjid dan Kuburan di Kabupaten Gowa Provinsi Sulawesi Selatan”. Salah satu kesimpulannya menyebutkan banyak penyimpangan arah kiblat masjid dan kuburan di Kabupaten Gowa Sulawesi Selatan yang diakibatkan (1) Pengetahuan yang kurang memadai, (2) Kurangnya pendidikan dan pelatihan, (3) Kurangnya imajinasi tentang masa depan, (4) Ketergantungan pada pihak lain, (5) Ketidaktahuan, kalalaian, dan kecerobohan, dan (6) Kurangnya kemampuan untuk berkomunikasi. Penelitian Abdul Jalil dan Hosen dengan judul "Qibla Jurisprudence: Deviation of Mosques' Qibla in Pamekasan Madura” melaporkan bahwa salah satu penyebab masih banyak arah kiblat masjid di Madura yang tidak tepat menghadap kiblat karena masih ada jamaah yang menganggap bahwa arah kiblat di Indonesia adalah arah barat. ${ }^{6}$ Pemahaman arah kiblat Indonesia ke arah barat membuat ada beberapa tokoh agama yang menolak hasil pengukuran arah kiblat dengan menggunakan alat teknologi. $^{7}$

${ }^{3}$ Zainul Arifin, "Toleransi Penyimpangan Pengukuran Arah Kiblat," ELFALAKY 2, No. 1 (13 Juni 2018), https://doi.org/10.24252/ifk.v2i1.14159.

${ }^{4}$ Anisah Budiwati, "Akurasi Arah Kiblat Masjid di Ruang Publik," JSSH (Jurnal Sains Sosial dan Humaniora) 2, no. 1 (2018): 159-73.

${ }^{5}$ Rahmatiah H., "Pengaruh Human Eror Terhadap Akurasi Arah Kiblat Masjid Dan Kuburan Di Kabupaten Gowa Provinsi Sulawesi Selatan," ELFALAKY 4, No. 2 (13 Desember 2020), https://doi.org/10.24252/ifk.v4i2.18069.

${ }^{6}$ Abdul Jalil dan Hosen Hosen, "Qibla Jurisprudence: Deviation of Mosques' Qibla in Pamekasan Madura," Islamuna: Jurnal Studi Islam 7, No. 2 (21 Desember 2020): 143-65, https://doi.org/10.19105/islamuna.v7i2.3381.

${ }^{7}$ Muthmainnah Muthmainnah dan Fattah Setiawan Santoso, "Pemanfaatan Sains Dan Teknologi Dalam Pengukuran Arah Kiblat Di Indonesia," Ulumuddin : Jurnal Ilmu-Ilmu Keislaman 10, no. 2 (29 Desember 2020): 149-62, https://doi.org/10.47200/ulumuddin.v10i2.441. 
Berangkat dari dinamika tersebut, persoalan arah kiblat di Indonesia masih sangan relevan untuk dibahas, tulisan ini mencoba menemukan sebuah rumusan yang standar untuk toleransi pelencengan arah kiblat bagi wilayah Indonesia. Standar toleransi ini sangat berguna bagi para teknisi pengukur arah kiblat di lapangan dan para akademisi peneliti arah kiblat, di mana dengan adanya nilai standar toleransi ini akan menjadi acuan dalam menetapkan bahwa sebuah masjid itu pas arah kiblat atau melenceng.

\section{B. Dasar Hukum Arah Kiblat di Indonesia}

Menghadap kiblat dalam salat merupakan salah satu syarat sahnya salat. Kiblat bagi orang yang bisa melihat Ka'bah adalah bangunan Ka'bah itu sendiri atau disebut 'ainul Ka'bah, tidak ada perbedaan pendapat ulama pada masalah tersebut. Yang menjadi perbedaan pendapat ulama fikih dalam menghadap kiblat adalah saat orang salat yang jauh dari Ka'bah seperti masyarakat muslim Indonesia. Ada yang berpendapat harus menghadap 'ainul Ka'bah dengan cara berijtihad sehingga menghasilkan dhanni (dugaan kuat) bahwa arah yang dihadap benar-benar arah 'ainul Ka'bah, ada yang berpendapat boleh menghadap jihat Ka'bah saja. ${ }^{8}$ Perbedaan pendapat ulama fikih dalam persoalan menghadap kiblat tersebut berpengaruh pada keakuratan arah pembangunan masjid dan berpengaruh juga pada respon terhadap upaya kalibrasi arah kiblat masjid yang diyakini arahnya tidak mengarah kepada posisi arah Ka'bah. Merespon persoalan umat tersebut, lembaga ulama Indonesia yang memiliki legalitas fatwa merespon persoalan kiblat masyarakat Indonesia dengan mengeluarkan fatwa tentang arah kiblat.

\section{Fatwa MUI Nomor 5 Tahun 2010}

Fatwa Majelis Ulama Indonesia (MUI) Nomor 5 Tahun 2010 merupakan fatwa yang dikeluarkan oleh MUI dalam rangka menjawab dinamika arah kiblat masjid di Indonesia, di mana pada tahun 2010 merupakan puncak isu pergeseran

\footnotetext{
${ }^{8}$ Teungku Mustafa Muhammad Isa, Fiqih Falakiyah (Yogyakarta: Deepublish, 2016), $141-$
} 143. 
arah kiblat di Indonesia yang meresahkan masyarakat dalam beribadah. ${ }^{9}$ Ada tiga poin yang diputuskan dalam fatwa tersebut: (1) Kiblat bagi orang yang salat dan dapat melihat Ka'bah adalah menghadap ke bangunan Ka'bah ('ainul Ka'bah). (2) Kiblat bagi orang yang salat dan tidak dapat melihat Ka'bah adalah arah Ka'bah (jihat al-Ka'bah). (3) Kiblat umat Islam Indonesia adalah menghadap ke barat laut dengan posisi bervariasi sesuai dengan letak kawasan masing-masing. Fatwa ini ditetapkan di Jakarta 18 Rajab 1431 H yang bertepatan pada tanggal 01 Juli 2010 M. ${ }^{10}$

Ketiga diktum tersebut dapat dijelaskan bahwa yang dimaksud dengan "jihat al-Ka'bah" dalam diktum keputusan poin 2 adalah arah terdekat dari Indonesia ke Ka'bah dalam lingkaran besar, hal ini dipahami dari diktum keputusan poin 3 yang menyebutkan arah kiblat bagi umat muslim Indonesia adalah arah barat laut dengan nilai azimut bervariasi dari Sabang sampai Merauke. Penyebutan "bervariasi" dalam diktum nomor 3 memastikan bahwa yang dimaksud dengan “jihat al-Ka'bah” dalam diktum nomor 2 bukan arah satu sudut 90 derajat atau dua sudut 180 derajat di mana di dalam nya terdapat posisi arah Ka'bah. Pengertian arah kiblat dalam Fatwa MUI nomor 5 tahun 2010 sesuai dengan pendapat kuat tentang arah kiblat dalam mazhab imam Syafi'i.

2. Fatwa MPU Aceh Nomor 3 Tahun 2018.

Fatwa Majelis Permusyawaratan Ulama (MPU) Aceh Nomor 3 Tahun 2018 merupakan sebuah fatwa yang dikeluarkan oleh MPU Aceh untuk menyikapi polimik arah kiblat dalam masyarakat Aceh. Maraknya pengukuran ulang (kalibrasi) arah kiblat di Aceh mengakibatkan keresahan dan tidak sedikit terjadi komplik di tengah masyarakat Aceh. Ada yang secara terbuka menerima hasil kalibrasi arah kiblat masjid dan ada yang tidak menerima dengan berbagai alasan. Salah satu alasan yang muncul dalam masyarakat adalah pemahaman arah kiblat antara jihat Ka'bah dengan 'ainul Ka'bah. Kehadiran fatwa MPU Aceh ini

\footnotetext{
${ }^{9}$ Kementerian Agama RI, Ephemeris Hisab Rukyat, 2020 (Jakarta: Direktorat Urusan Agama Islam dan Pembinaan Syariah, 2019), 411-420.

${ }^{10}$ Ibid., 420.
} 
bertujuan untuk meluruskan dan menyatukan persepsi arah kiblat bagi masyarakat Aceh. Hal ini bisa dilihat dari pertimbangan lahirnya fatwa MPU tersebut pada poin a dan b dalam fatwa MPU Aceh Nomor 3 Tahun 2018. ${ }^{11}$

Poin penting dalam fatwa ini tentang arah kiblat adalah terdapat pada poin keempat dalam diktum keputusan hasil fatwa. Dalam poin keempat disebutkan "kiblat bagi orang yang shalat dan tidak dapat melihat ka'bah adalah menghadap bangunan ka'bah secara zhanni". Maksud kiblat "zhanni” dalam fatwa MPU Aceh Nomor 3 Tahun 2018 sama dengan pengertian kiblat “jihat al-Ka'bah" dalam diktum fatwa MUI Nomor 5 tahun 2010. Kedua diktum tersebut menjelaskan bahwa arah kiblat bagi masyarakat muslim Indonesia adalah nilai azimut arah dengan arah terdekat yang dihasilkan di sebuah lokasi dalam konsep lingkaran besar. Jadi kedua fatwa ini sama dalam memberi solusi makna arah kiblat bagi muslim Indonesia dan kedua fatwa ini menitikberatkan arah kiblat dalam membangun masjid, hal ini bisa dilihat dari isi taushiyah yang ada dalam fatwa MPU Aceh Nomor 3 Tahun 2018 dan fatwa MUI Nomor 5 Tahun 2010 yang menekankan pada kesesuaian arah saf masjid dengan arah kiblat.

Bila merujuk pada dua fatwa tersebut, dapat disimpulkan bahwa arah kiblat bagi masyarakat muslim Indonesia adalah arah bangunan Ka'bah yang disebut dangan arah kiblat dhanni dalam fatwa MPU Aceh nomor 3 tahun 2018. Artinya arah kiblat bagi masyarakat muslim Indonesia adalah nilai arah hasil perhitungan secara ilmu falak yang menunjuki arah posisi bangunan Ka'bah di Masjidilharam Makkah. Hal ini sesuai dengan apa yang dikenal dalam ilmu falak, arah kiblat merupakan arah terdekat dalam sebuah lingkaran besar yang dihitung dari posisi seseorang ke Ka'bah. ${ }^{12}$ Oleh karenanya, yang dimaksud dengan mengadap kiblat dalam salat adalah posisi badan orang yang sedang mengerjakan salat sesuai dengan posisi arah hasil perhitungan di mana posisi orang yang salat itu berada, misalnya posisi 292,1 derajat untuk Kota Lhokseumawe-Aceh merupakan posisi arah kiblat

\footnotetext{
${ }^{11}$ MPU Aceh, "Fatwa Majelis Permusyawaratan Ulama Aceh Nomor 3 Tahun 2018 Tentang Penetapan Arah Kiblat,” 2018, https://ppid2.acehprov.go.id/v2/dip/view/1430.

${ }^{12}$ Slamet Hambali, IImu Falak, Arah Kiblat Setiap Saat (Yogyakarta: Pustaka Ilmu, 2013). h. iv.
} 
yang harus diperhatikan dalam malaksanakan salat. Hal yang sama bila dikaitkan dengan ketepatan arah kiblat bagi sebuah bangunan masjid, arah masjid di Kota Lhokseumawe yang sesuai dengan arah kiblat adalah arah bangunan masjid yang sesuai dengan posisi arah 292,1 derajat. Bilai posisi badan orang yang salat dan posisi bangunan masjid di Kota Lhokseumawe tidak searah pada posisi 292,1 derajat, maka orang tersebut atau masjid tersebut dikatakan melenceng dari arah kiblat.

Namun perlu dicatat bahwa kedua fatwa tersebut ada penekanan kepada arah bangunan masjid di Indonesia, bukan arah badan orang yang sedang melaksanakan salat di Indonesia. Penekanan isi fatwa kepada arah bangunan masjid, bukan arah badan orang dalam masjid tentunya sangat ilmiah. Ada tiga alasan yang menguatkan agar isi fatwa tersebut diartikan untuk bangunan masjid. (1) Posisi bangunan masjid akan menjadi acuan posisi arah orang salat dalam masjid. (2) Masjid merupakan benda tetap yang mudah diposisikan kemana arah yang harus didirikan, berbeda dengan manusia yang tidak mampu berada pada posisi tetap seperti bangunan masjid. (3) Ukuran bangunan masjid yang besar akan berakibat sedikit saja pelencengan arah kiblat akan melenceng jauh arah yang dihadapkan, berbeda dengan tubuh manusia yang berukuran kecil, pergeseran dalam ukuran sedikit belum terlihat secara kasat mata. Sebagai perbandingan pelencengan, ukuran masjid dengan lebar 20 meter bila melenceng 6 derajat akan bergeser saf nya 2,10 meter, sedangkan bila badan manusia ditaksirkan dengan lebar 50 centimeter, maka pelencengan 6 derajat hanya bergeser 5,3 centimeter. Pergeseran badan manusia sekitar 5 centimeter itu belum terasa dan belum terlihat pergeseran bandan secara kasat mata.

\section{Geometri Arah Kiblat}

Umat Islam dalam melaksanakan salat diwajibkan menghadap arah kiblat sebagai salah satu syarat sahnya salat. Bagi muslim yang jauh dari Ka'bah seperti Indonesia tentunya harus memiliki konsep yang menghasilkan arah Ka'bah sebagai pedoman dalam menjalankan ibadah salat yang diperintahkan sebagai menghadap 
arah kiblat. Dengan bantuan ilmu geometri, arah Ka'bah bagi masyarakat muslim Indonesia walau posisi jauh dari Ka'bah dapat diketahui dengan mudah. Dalam perhitungan arah kiblat, ada tiga titik yang harus diketahui, yaitu (1) titik A sebagai posisi Ka'bah, (2) titik B sebagai lokasi yang hendak diketahui arah kiblat, dan (3) titik C sebagai titik kutub utara. Sebagaimana terlihat dalam gambar nomor 1 di bawah. ${ }^{13}$

Ketiga titik ini ditandai dengan nilai koordinat, yaitu lintang dan bujur lokasi. Lintang $(\varphi)$ adalah nilai panjang garis khayali yang dihitung dari garis khatulistiwa ke kutub Bumi. Panjang garis lintang dari garis khatulistiwa ke kutub utara adalah $90^{\circ}$ yang biasanya ditulis lintang utara (LU). Jarak dari khatulistiwa ke kutub selatan juga $90^{\circ}$ yang dikenal dengan lintang selatan (LS). Bujur ( $\lambda$ ) adalah nilai panjang garis khayali yang dihitung dari garis lintang Geenwich di London, Inggris ke timur sampai pada garis bujur $180^{\circ}$ yang biasanya disebutkan bujur timur (BT). Dari Greenwich ke barat sampai juga pada garis buju $180^{\circ}$ disebut bujur barat (BB). ${ }^{14}$

Garis bujur yang mempertemukan titik bujur timur dengan titik bujur barat pada bujur $180^{\circ}$ terletak di Samudra Pasifik dan dijadikan sebagai garis pergantian tanggal internasional, di mana saat Matahari berada pukul 12.00 (tengah hari) di meridian Greenwich (bujur $0^{\circ}$ ) di mana posisi Matahari berada di titik zenit, di meridian $180^{\circ}$ berada pada pukul 00.00 (tengah malam) di mana posisi Matahari berada di titik nadir, saat itu wilayah yang berada di bujur timur sudah memasuki tanggal baru dengan hari berikutnya, Senin 5 Januari misalnya, sedangkan yang bujur barat masih tanggal sebelumnya, yaitu Minggu 4 Januari. Seperti ini konsep pembagian waktu di dunia, di mana pergantian tanggal dan hari selalu terjadi saat pukul 00.00 (tengah malam) di titik meridian zona waktu, pukul 00.00 di meridian bujur $120^{\circ} \mathrm{BT}$ untuk Waktu Indonesia Tengah (WITA). Saat waktu melewati pukul

\footnotetext{
${ }^{13}$ Abu Sabda, Ilmu Falak, Rumusan Syar'i dan Astronomi. Waktu Shalat dan Arah Kiblat, 1 (Bandung: Persis Pers, 2019), 112.

${ }^{14}$ Slamet Hw, Dasar-dasar Ilmu Ukur Segitiga Bola: Menentukan Arah Kiblat, Waktu Sholat, Awal Bulan Qamariah, dan Gerhana. (Jawa Tengah: Muhammadiyah University Pres, 2018), 33-35.
} 
00.01 WITA, maka seluruh wilayah dalam zona waktu WITA telah masuk tanggal baru dengan hari berikutnya.

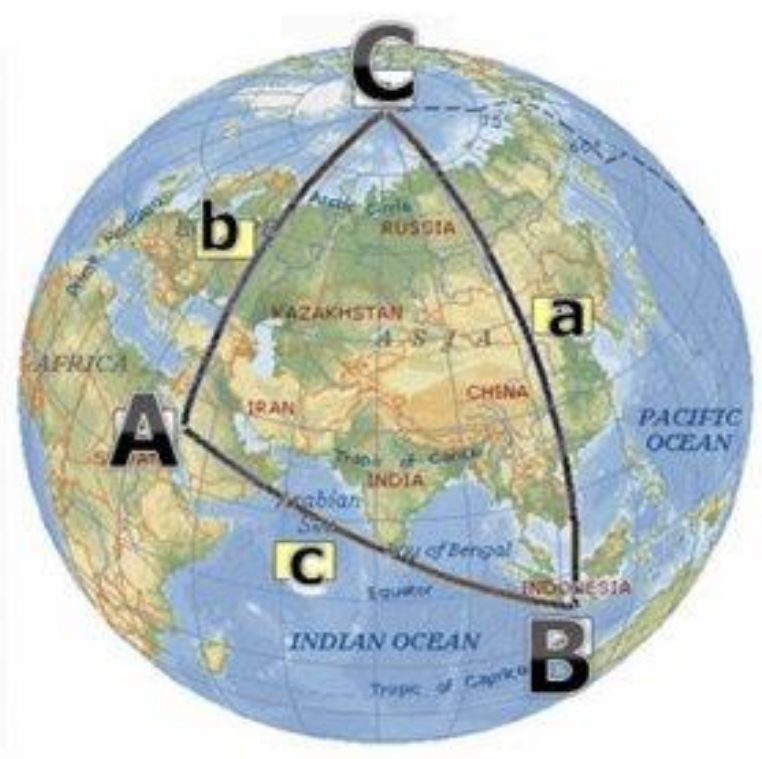

Gambar 1: Ilustrasi Segitiga Bola ${ }^{15}$

Titik A dan titik $\mathrm{C}$ adalah dua titik yang selalu tetap, tidak pernah berubahubah dalam perhitungan arah kiblat, karena titik A merupakan posisi Ka'bah di Makkah dan titik C merupakan titik kutub utara Bumi. Sedangkan titik B selalu berubah-ubah dalam perhitungan arah kiblat, karena tergantung lokasi di permukaan Bumi yang ingin diketahui arah kiblatnya. Bila ketiga titik tersebut dihubungkan dengan garis lengkung pada lingkaran besar, maka terjadilah segitiga bola $\mathrm{ABC}$, seperti yang terlihat dalam gambar nomor 1 di atas. Dari gambar tersebut dapat dijelaskan bahwa yang dimaksud dengan menghitung arah kiblat adalah menghitung berapa besarnya sudut B dari arah utara ke barat, yaitu sudut yang diapit oleh sisi a dan sisi b.

Secara teori segitiga bola, untuk mengetahui besaran nilai sudut $\mathrm{B}$, terlebih dahulu harus diketahui nilai dari sisi a, nilai dari sisi c, dan nilai dari sudut $\mathrm{C}$.

\footnotetext{
${ }^{15}$ sumber: https://aliboron.wordpress.com/2013/05/14/hisab-arah-kiblat-3/, diakses tanggal 4 Februari 2021.
} 
Sebagai contoh perhitungan arah kiblat di lokasi Masjid Agung Baiturrahim Kabupaten Gorontalo, sebagai berikut:

Data yang diperlukan:

1. Lintang tempat $(\varphi \mathrm{t}): 00^{\circ} 32^{\prime} 17^{\prime \prime} \mathrm{LU}$.

2. Bujur tempat $(\lambda t): 123^{\circ} 03^{\prime} 37^{\prime \prime}$ BT.

3. Lintang Ka’bah ( $\varphi \mathrm{k}): 21^{\circ} 25^{\prime} 21^{\prime \prime} \mathrm{LU}$.

4. Bujur Ka’bah $(\lambda \mathrm{k}): 39^{\circ} 49^{\prime} 34^{\prime \prime} \mathrm{BT}$.

Mencari sisi dan sudut:

Sisi a $\quad=90^{\circ}-\varphi \mathrm{t}$

Sisi $\mathrm{b} \quad=90^{\circ}-\varphi \mathrm{k}$.

$$
\begin{aligned}
& =90^{\circ}-00^{\circ} 32^{\prime} 17^{\prime \prime} . \\
& =89^{\circ} 27^{\prime} 43^{\prime \prime} .
\end{aligned}
$$

$$
\begin{aligned}
& =90^{\circ}-21^{\circ} 25^{\prime} 21^{\prime \prime} . \\
& =68^{\circ} 34^{\prime} 39^{\prime \prime} . \\
\text { Sudut C } \quad & =\lambda \mathrm{t}-\lambda \mathrm{k} \\
& =123^{\circ} 03^{\prime} 37^{\prime \prime}-39^{\circ} 49^{\prime} 34^{\prime \prime} . \\
& =83^{\circ} 14^{\prime} 03^{\prime \prime} .
\end{aligned}
$$

Menghitung arah kiblat dengan rumus:

Sudut B

$$
\begin{aligned}
= & \frac{\operatorname{Cotg} b \times \operatorname{Sin} a}{\operatorname{Sin} C}-\operatorname{Cos} a \times \operatorname{Cotg} C^{16} \\
= & \operatorname{Cotg}^{17} 68^{\circ} 34^{\prime} 39^{\prime \prime} \times \operatorname{Sin} 89^{\circ} 27^{\prime} 43^{\prime \prime}: \operatorname{Sin} 83^{\circ} 14^{\prime} 03^{\prime \prime}-\operatorname{Cos} 89^{\circ} \\
& 27^{\prime} 43^{\prime \prime} \times \operatorname{Cotg} 83^{\circ} 14^{\prime} 03^{\prime \prime} . \\
= & 0,393971657^{18} \\
= & 68^{\circ} 29^{\prime} 49,08^{\prime \prime} .(\text { arah kiblat dari titik utara ke barat). } \\
= & 90^{\circ}-68^{\circ} 29^{\prime} 49,08^{\prime \prime} \\
= & 21^{\circ} 30^{\prime} 10,92^{\prime \prime} . \text { (arah kiblat dari barat ke utara). }
\end{aligned}
$$

${ }^{16}$ Alfirdaus Putra, Cepat \& Tepat Arah Kiblat (Yogyakarta: Elmatera, 2015). h. 33-35.

${ }^{17}$ Cotg pada kalkulator ditekan $1 /$ tan.

${ }^{18}$ Untuk mendapakan nilai dalam satuan derajat, tekan Shiff tan $(1 /($ ans $))$. Setelah keluar hasil, maka tekan tombol derajat. 


$$
\begin{aligned}
& =270^{\circ}+21^{\circ} 30^{\prime} 10,92^{\prime \prime} \\
& =291^{\circ} 30^{\prime} 10,9^{\prime \prime} . \text { (arah kiblat secara azimut kompas). }
\end{aligned}
$$

Berdasarkan perhitungan tersebut dapat disimpulkan bahwa arah kiblat bagi Kabupaten Gorontalo adalah arah $68^{\circ} 29^{\prime} 49,08^{\prime \prime}$ dari titik utara ke barat, atau arah $21^{\circ} 30^{\prime} 10,92^{\prime \prime}$ dari titik barat ke utara, atau arah $291^{\circ} 30^{\prime} 10,9^{\prime \prime}$ secara azimut kompas. Jadi, menghadap arah kiblat dalam salat bagi penduduk Kabupaten Gorontalo adalah menghadap badannya ke arah tersebut dalam setiap posisi salatnya. Tempat ibadah seperti masjid dan musala yang tepat arah kiblatnya dalam Kabupaten Gorontalo adalah posisi bangunan masjid dan musala yang posisi bangunannya searah dengan arah kiblat tersebut. Secara matemastis, bila bangunan masjid atau musalla tidak sesuai posisi arahnya dengan arah kiblat, maka masjid dan musalla tersebut dikatakan melenceng arah kiblat. Mendirikan bangunan masjid atau musalla dengan posisi persis seperti pada nilai arah kiblat hasil perhitungan, bukan sebuah persoalan yang mudah, begitu juga dengan memposisikan badan dalam salat agar persis dengan nilai arah kiblat. Di sini perlu ada nilai pelencengan badan saat salat atau pelencengan arah bangunan masjid dan musalla yang diperbolehkan melenceng dari nilai arah kiblat hasil perhitungan yang dikenal dengan toleransi pelencengan arah kiblat.

\section{Toleransi Pelencengan Arah Kiblat Kaitannya dengan Fikih Salat}

Toleransi menurut Kamus Besar Bahasa Indonesia (KBBI) diartikan sebagai batas ukur untuk penambahan atau pengurangan yang masih diperbolehkan. Dalam konteks arah kiblat, yang dimaksud toleransi adalah batasan pelencengan yang masih diperbolehkan dalam menghadap kiblat. Ada dua macam standar toleransi pelencengan dalam perhitungan arah kiblat: (1) Toleransi secara matematis, yaitu batas toleransi pelencengan arah kiblat yang dihasilkan dari kontruksi rumusan matematis. (2) Toleransi secara sosiologis, yaitu batas toleransi pelencengan arah kiblat yang dibangun atas dasar konstruksi sosial dalam menghasilkan arah kiblat. 
Secara matematis, jarak suatu tempat di atas permukaan Bumi ke Ka'bah dapat diketahui, serta jarak pelencengan arah kiblat juga dapat diketahui. Sebagai contoh dapat dihitung jarak lokasi Masjid Agung Baiturrahim Kabupaten Gorontalo ke Ka'bah dan jarak pelencengan dalam satuan kilometer dari Ka'bah bila terjadi pergeseran arah kiblat masjid di Kabupaten Gorontalo dengan perhitungan sebagai berikut:

Data yang diketahui:

1. Lintang tempat $(\varphi \mathrm{t}): 00^{\circ} 32^{\prime} 17^{\prime \prime} \mathrm{LU}$.

2. Bujur tempat $(\lambda \mathrm{t}): 123^{\circ} 03^{\prime} 37^{\prime \prime} \mathrm{BT}$.

3. Lintang Ka'bah ( $\varphi \mathrm{k}): 21^{\circ} 25^{\prime} 21^{\prime \prime} \mathrm{LU}$.

4. Bujur Ka’bah $(\lambda \mathrm{k}): 39^{\circ} 49^{\prime} 34^{\prime \prime} \mathrm{BT}$.

$$
\begin{aligned}
\mathrm{U} & =(\varphi \mathrm{t}+\varphi \mathrm{k}) / 2 . \\
& =\left(00^{\circ} 32^{\prime} 17^{\prime \prime}+21^{\circ} 25^{\prime} 21^{\prime \prime}\right) / 2 . \\
& =10^{\circ} 58^{\prime} 49^{\prime \prime} . \\
\mathrm{G} & =(\varphi \mathrm{t}-\varphi \mathrm{k}) / 2 \\
& =\left(00^{\circ} 32^{\prime} 17^{\prime \prime}-21^{\circ} 25^{\prime} 21^{\prime \prime}\right) / 2 . \\
& =-10^{\circ} 26^{\prime} 32^{\prime \prime} . \\
\mathrm{J} & =(\lambda \mathrm{t}-\lambda \mathrm{k}) / 2 . \\
& =\left(123^{\circ} 03^{\prime} 37^{\prime \prime}-39^{\circ} 49^{\prime} 34^{\prime \prime}\right) / 2 \\
& =41^{\circ} 37^{\prime} 1,5^{\prime \prime} . \\
\mathrm{M} & =\sin (\mathrm{G}) \mathrm{x} \sin (\mathrm{G}) \times \cos (\mathrm{J}) \mathrm{x} \cos (\mathrm{J})+\cos (\mathrm{U}) \times \cos (\mathrm{U}) \times \sin (\mathrm{J}) \times \sin (\mathrm{J}) . \\
& =\sin \left(-10^{\circ} 26^{\prime} 32^{\prime \prime}\right) \times \sin \left(-10^{\circ} 26^{\prime} 32^{\prime \prime}\right) \times \cos \left(41^{\circ} 37^{\prime} 1,5^{\prime \prime}\right) \times \cos \left(41^{\circ} 37^{\prime}\right. \\
& \left.1,5^{\prime \prime}\right)+\cos \left(10^{\circ} 58^{\prime} 49^{\prime \prime}\right) \times \cos \left(10^{\circ} 58^{\prime} 49^{\prime \prime}\right) \mathrm{x} \sin \left(41^{\circ} 37^{\prime} 1,5^{\prime \prime}\right) \mathrm{x} \sin \left(41^{\circ}\right. \\
& \left.37^{\prime} 1,5^{\prime \prime}\right) . \\
& =0,44345123 .
\end{aligned}
$$




$$
\begin{aligned}
& \mathrm{N}=\cos (\mathrm{G}) \times \cos (\mathrm{G}) \times \cos (\mathrm{J}) \times \cos (\mathrm{J})+\sin (\mathrm{U}) \times \sin (\mathrm{U}) \times \sin (\mathrm{J}) \times \sin (\mathrm{J}) . \\
& =\cos \left(-10^{\circ} 26^{\prime} 32^{\prime \prime}\right) \times \cos \left(-10^{\circ} 26^{\prime} 32^{\prime \prime}\right) \times \cos \left(41^{\circ} 37^{\prime} 1,5^{\prime \prime}\right) \times \cos \left(41^{\circ} 37^{\prime}\right. \\
& \left.1,5^{\prime \prime}\right)+\sin \left(10^{\circ} 58^{\prime} 49^{\prime \prime}\right) \times \sin \left(10^{\circ} 58^{\prime} 49^{\prime \prime}\right) \times \sin \left(41^{\circ} 37^{\prime} 1,5^{\prime \prime}\right) \times \sin \left(41^{\circ}\right. \\
& \left.37^{\prime} 1,5^{\prime \prime}\right) \\
& =0.556548769 \text {. } \\
& \mathrm{W}=\tan ^{-1} \sqrt{\frac{\mathrm{M}}{\mathrm{N}}} \\
& =\tan ^{-1} \sqrt{\frac{0,44345123}{0,556548769}}=41,75304692^{19} \times \pi / 180=0,728728141 \\
& =0,728728141 \text {. } \\
& \mathrm{P}=\frac{\sqrt{\mathrm{M} \times \mathrm{N}}}{\mathrm{w}} \\
& =\sqrt{\frac{0,44345123 \times 0,556548769}{0,728728141}}=0,838938776^{20} \\
& =0,68172466 \text {. } \\
& \mathrm{D}=2 \times \mathrm{W} \times \mathrm{a} \text {, di mana } \mathrm{a}=6378,137 \text { kilometer. } \\
& =2 \times 0,728728141 \times 6378,137 \\
& =9295,855838 \text {. } \\
& \mathrm{E} 1=(3 \times \mathrm{P}-1) /(2 \times \mathrm{N}) \\
& =(3 \times 0,68172466-1) /(2 \times 0.556548769) \\
& =0,938977892 \text {. } \\
& \mathrm{E} 2=(3 \times \mathrm{P}+1) /(2 \times \mathrm{M}) \\
& =(3 \times 0,68172466+1) /(2 \times 0,44345123) \\
& =3,433493667 \text {. }
\end{aligned}
$$

Sehingga jarak antara lokasi Masjid Agung Baiturrahim Kabupaten Gorontalo dan Ka'bah (S) adalah:

\footnotetext{
${ }^{19}$ Cara pencet kalkulator Casio fx-350MS, shift tan $\operatorname{akar}(0,44345123 / 0.556548769)=$ 41,75304692 .

${ }^{20}$ Cara pencet kalkulator Casio fx-350MS, akar(0,44345123 x 0.556548769$) / 0,728728141$ $=0,68172466$.
} 


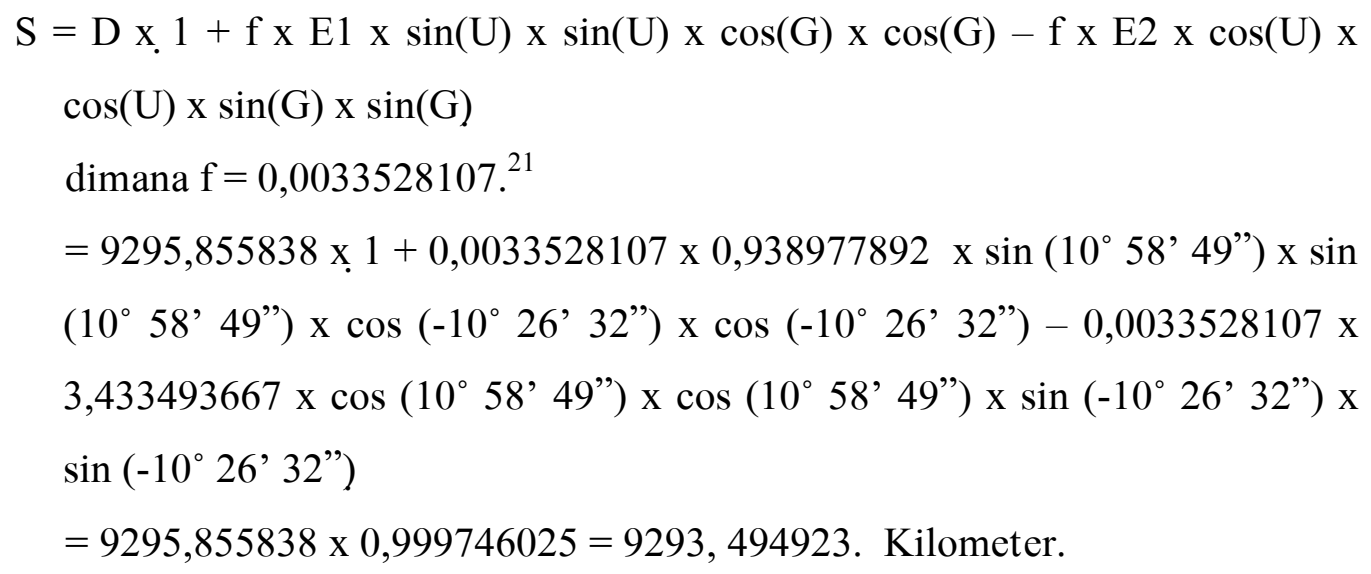

Jadi, jarak antara lokasi Masjid Agung Baiturrahim Kabupaten Gorontalo ke Ka’bah adalah 9293, 494923 kilometer.

Jarak pelencengan 1 derajat $=\frac{\mathrm{s} \times 1 \times \pi}{180}=\frac{9293,494923 \times 1 \times \pi}{180}=162,2020854$ kilometer. Jadi jarak pelencengan dari Ka'bah ke kiri atau ke kanan dalam setiap satu derajat busur adalah 162,2020854 kilometer.

\section{Toleransi Secara Matematis}

Secara matematis bisa disebutkan tidak ada toleransi pelencengan arah kiblat, secara matematis arah $291^{\circ} 30^{\prime} 10,9^{\prime \prime}$ sebagai arah kiblat di Kabupaten Gorontalo bisa diketahui dan semua bangunan masjid juga bisa dibangun searah dengan nilai arah kiblat tersebut. Namun demikian, secara matematis dapat juga dibangun nilai toleransi pelencengan arah kiblat atas dasar dua dalil:

a. Hadis Qauli Rasulullah

Hadis qauli Rasulullah SAW. yang menjelaskan ada ruang toleransi pelencengan arah kiblat. Artinya, tidak selamanya perintah menghadap bangunan Ka'bah bagi seluruh penduduk Bumi yang jauh dari Kota Makkah. Hadis yang diriwayatkan oleh Ibnu Hibban dari Ibnu Abbas Ra. memberikan informasi

\footnotetext{
${ }^{21}$ Ismail Ismail, "Standar Operasional Prosedur (SOP) Kalibrasi Arah Kiblat Masjid Di Era Digital," Al-Marshad: Jurnal Astronomi Islam dan Ilmu-Ilmu Berkaitan, Vol. 5, No. 1 (2 Juni 2019), https://doi.org/10.30596/jam.v5i1.3126. 102-105.
} 
kelonggaran bangi penduduk Bumi tidak mesti mengadap bangunan Ka'bah saat melakukan salat.

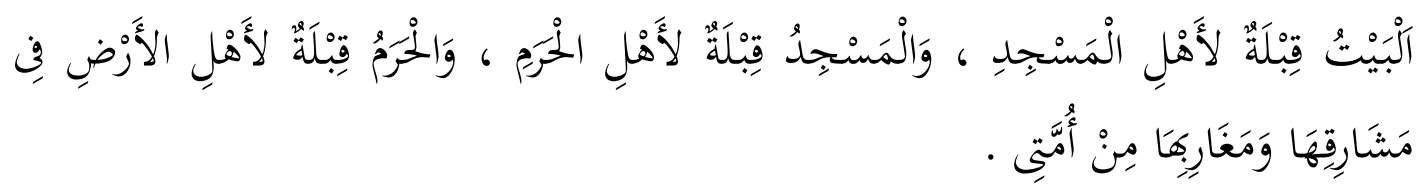

Artinya:

Ka'bah itu menjadi kiblat bagi orang yang berada dalam Masjidilharam, Masjidilharam menjadi kiblat bagi orang yang berada dalam tanah haram, dan tanah haram menjadi kiblat bagi orang yang berada di luar tanah haram dari arah timur dan arah barat umat Nabi Muhammad saw. (HR. Ibnu Hibban. Nomor 2324).

Hadis Rasulullah saw. yang diriwayatkan oleh Ibnu Hibban dapat dipahami dengan jelas, untuk penduduk muslim yang jauh dari Masjidilharam seperti Indonesia diperbolehkan menghadap tanah haram saja. Ada toleransi yang bisa dipahami dari hadis tersebut. Ka'bah yang awalnya berukuran kecil kemudian diasumsikan menjadi Ka'bah besar seukuran besaran Masjidilharam, kemudian seukuran tanah haram Makkah. Lokasi tanah haram Makkah ditandai dengan tapal batas yang biasanya dijadikan tempat niat orang melakukan ibadah haji dan umrah. Dari hadis ini bisa dipahami, kewajiban mengahadap kiblat dalam salat bagi yang jauh dari Masjidilharam tidak mesti menghadap arah bangunan Ka'bah, namun diperbolehkan menghadap arah lain yang lebih luas dari Ka'bah yaitu luas arah tanah haram.

\section{b. Hadis Fi'li Rasulullah}

Hadis fi'li adalah perbuatan Rasulullah SAW. dalam mendirikan Masjid Quba, di mana arah kiblat masjid ini bisa dijadikan rujukan dalam membangun toleransi pelencengan arah kiblat secara matematis bagi daerah yang jauh dari Ka'bah seperti Indonesia. Masjid Quba merupakan masjid pertama yang dibangun langsung oleh Rasulullah beserta kaum muslimin yang berjarak 336 kilometer dari Ka'bah. Partisipasi Rasulullah dalam membangun Masjid Quba bisa disebutkan hadis fi'li yang dapat dijadikan dalil terhadap toleransi pelencengan arah kiblat 
masjid yang berpatokan pada arah kiblat Masjid Quba. Masjid Quba yang berbentuk persegi panjang terletak pada koordinat $24^{\circ} 26^{\prime} \mathrm{LU}, 39^{\circ} 37^{\prime} \mathrm{BT}^{22}$

Arah Masjid Quba tidak persis mengahdap ke arah bangunan Ka'bah di Kota Makkah, namun bergeser 45 kilometer di sebalah barat Ka'bah dengan selisih dari arah kiblat $7^{\circ} 38^{\prime}$ busur. Jarak 45 kilometer ini bisa dijadikan jarak jari-jari sebuah lingkaran yang berpusat di Ka'bah. Dalam artian, lingkarang dengan jari-jari 45 kilometer ini diasumsikan sebagai laus Ka'bah yang boleh dihadap oleh umat Islam saat melakukan salat yang jauh dari Kota Makkah. Atas dasar asumsi tersebut dibuat sebuah turunan rumus yang dinamakan rumus toleransi pelencengan arah kiblat secara matematis. Perlu penekanan, bahwa dalam hal posisi Masjid Quba yang dijadikan batas toleransi pelencengan arah kiblat bukan pada nilai pelencengan posisi Masjid Quba $7^{\circ}$ 38' tersebut, tetapi arah Masjid Quba yang dihasilkan 45 kilometer dari posisi Ka'bah.

Untuk menghitung simpangan arah kiblat yang diperkenankan di Kabupaten Gorontalo, perlu dilakukan tahapan-tahapan sebagai berikut:

1) Data yang diperlukan

Lintang tempat $(\varphi \mathrm{t}): 00^{\circ} 32^{\prime} 17^{\prime \prime} \mathrm{LU}$.

Bujur tempat $(\lambda t): 123^{\circ} 03^{\prime} 37^{\prime \prime}$ BT.

Lintang Ka'bah ( $\varphi k): 21^{\circ} 25^{\prime} 21^{\prime \prime} \mathrm{LU}$.

Bujur Ka’bah $(\lambda \mathrm{k})$ : 39 49’34" BT.

2) Menghitung sudut dan sisi.

Sisi a $=90^{\circ}$ - Lintang tempat

$$
\begin{aligned}
& =90^{\circ}-00^{\circ} 32^{\prime} 17^{\prime \prime} \\
& =89^{\circ} 27^{\prime} 43^{\prime \prime}
\end{aligned}
$$

Sisi $\mathrm{b}=90^{\circ}$ - Lintang Ka'bah

$$
\begin{aligned}
& =90^{\circ}-21^{\circ} 25^{\prime} 21^{\prime \prime} \\
& =68^{\circ} 34^{\prime} 39^{\prime \prime}
\end{aligned}
$$

Sudut C = Bujur tempat - Bujur Ka'bah

\footnotetext{
${ }^{22}$ Muh. Ma'rufin Sudibyo, Sang Nabi Pun Berputar, Arah kiblat dan tata cara pengukurannya. (Solo: Tinta Medina, 2011). h. 83-86.
} 


$$
\begin{aligned}
& =123^{\circ} 03^{\prime} 37^{\prime \prime}-39^{\circ} 49^{\prime} 34^{\prime \prime} \\
& =83^{\circ} 10^{\prime} 26^{\prime \prime}
\end{aligned}
$$

Sisi $\mathrm{c}=\operatorname{Cos} \mathrm{c}=\operatorname{Cos} \mathrm{a} \times \operatorname{Cos} \mathrm{b}+\operatorname{Sin} \mathrm{a} \times \operatorname{Sin} \mathrm{b} \times \operatorname{Cos} \mathrm{C}$

$\operatorname{Cos} \mathrm{c}=\operatorname{Cos} 89^{\circ} 27^{\prime} 43^{\prime \prime} \mathrm{x} \operatorname{Cos} 68^{\circ} 34^{\prime} 39^{\prime \prime}+\operatorname{Sin} 89^{\circ} 27^{\prime} 43^{\prime \prime} \mathrm{x}$

$\operatorname{Sin} 68^{\circ} 34^{\prime} 39^{\prime \prime} \mathrm{x} \operatorname{Cos} 83^{\circ} 10^{\prime} 26^{\prime \prime}$.

$=0,114069977$ (shift $\cos$ Ans $\left.={ }^{\circ} " \prime\right)$

$\mathrm{c}=83^{\circ} 27^{\prime} 00,05^{\prime \prime}$

Sudut $\mathrm{B}=\operatorname{Sin} \mathrm{B}=\operatorname{Sin} \mathrm{b} \times \operatorname{Sin} \mathrm{C} / \operatorname{Sin} \mathrm{C}$

$$
\begin{aligned}
& =\operatorname{Sin}^{-1}(\operatorname{Sin} \mathrm{b} x \operatorname{Sin} \mathrm{C} / \operatorname{Sin} \mathrm{c}) \\
& =\operatorname{Sin}^{-1}\left(\operatorname{Sin} 68^{\circ} 34^{\prime} 39^{\prime \prime} \text { x } \operatorname{Sin} 83^{\circ} 27^{\prime} 00,05^{\prime \prime} / \operatorname{Sin} 83^{\circ} 27^{\prime}\right. \\
& \left.00,05^{\prime \prime}\right) \\
& =68^{\circ} 34^{\prime} 39^{\prime \prime}
\end{aligned}
$$

Sudut $A=\operatorname{Sin} A=\operatorname{Sin} a x \operatorname{Sin} B / \operatorname{Sin} b$

$$
\begin{aligned}
& =\operatorname{Sin}^{-1}(\operatorname{Sin} \mathrm{x} \operatorname{Sin} \mathrm{B} / \operatorname{Sin} \mathrm{c}) \\
& =\operatorname{Sin}^{-1}\left(\operatorname{Sin} 89^{\circ} 27^{\prime} 43^{\prime \prime} \text { x } \operatorname{Sin} 68^{\circ} 34^{\prime} 39^{\prime \prime} / \operatorname{Sin} 68^{\circ} 34^{\prime} 39^{\prime \prime}\right) \\
& =89^{\circ} 27^{\prime} 43^{\prime \prime}
\end{aligned}
$$

3) Menghitung sisi bantu dan simpangan yang diperkenankan

$$
\begin{aligned}
\text { Sisi bantu K } & =(0,0071 / \operatorname{Cos}(\mathrm{A}-90)) \\
& =\left(0,0071 / \operatorname{Cos}\left(89^{\circ} 27^{\prime} 43^{\prime \prime}-90^{\circ}\right)\right) \\
& =7,100313079\left(\text { shift } \operatorname{Tan}={ }^{\circ \prime \prime}\right) \\
& =0^{\circ} 24^{\prime} 24,52^{\prime \prime}
\end{aligned}
$$

Simpangan yang diperkenankan $(\Delta \mathrm{K})$

$\Delta \mathrm{K}=\operatorname{Sin} \mathrm{K} x \operatorname{Sin} \mathrm{C} / \mathrm{Sin} \mathrm{c}$

$=\operatorname{Sin} 0^{\circ} 24^{\prime} 24,52^{\prime \prime} \times \operatorname{Sin} 83^{\circ} 10^{\prime} 26^{\prime \prime} / \operatorname{Sin} 83^{\circ} 27^{\prime} 00,05^{\prime \prime}$

$=7,096122383$ (shift $\left.\operatorname{Sin}={ }^{\circ \prime \prime}\right)$

$$
\Delta \mathrm{K}=0^{\circ} 24^{\prime} 23,69^{\prime \prime 2}
$$

Jadi simpangan arah kiblat yang diperbolehkan untuk Kabupaten Gorontalo adalah $00^{\circ} 24^{\prime} 23,69^{\prime \prime}$ baik ke kiri atau ke kanan Ka'bah. Bila dibuat dalam bentuk

${ }^{23}$ Ismail Ismail, "Urgensi Dan Legitimasi Fatwa Majelis Permusyawaratan Ulama Aceh Nomor 3 Tahun 2018 tentang Penetapan Arah Kiblat," Al-Manahij: Jurnal Kajian Hukum Islam, Vol. 14, No. 1 (2 Juni 2020): 87-98, https://doi.org/10.24090/mnh.v14i1.3669; 59. 
nilai azimut, arah toleransi pelencengan arah kiblat secara matematis di Kabupaten Gorontalo berada dalam rentang azimut $291^{\circ} 05^{\prime} 47,21^{\prime \prime}-291^{\circ} 54^{\prime} 34,5^{\prime \prime}$. Artinya, bila hasil kalibrasi sebuah masjid di Kabupaten Gorontalo menunjuki azimut bangunan berada dalam rentang tersebut maka masjid tersebut dianggap tepat arah kiblatnya, karena sesuai dengan arah kiblat Masjid Quba. Secara matematis, persoalan arah kiblat bisa ditentukan dengan mudah, apakah arah Ka'bah, arah Masjidilharam, arah tanah hamaram, atau arah Kota Makkah. Artinya, arah bagunan masjid bisa dengan mudah diarahkan posisi bangunan nya searah dengan arah kiblat, karena hasil perhitungan arah kiblat di suatu lokasi bisa dijadikan pedoman dalam memposisikan arah bangunan sebuah masjid.

Secara matematis, sebuah bangunan juga bisa diarahkan pada posisi Masjidilharam ('ainul Masjidilharam). Titik utara Masjidilharam berada pada koordinat $21^{\circ} 25^{\prime} 32^{\prime \prime} \mathrm{LU}, 39^{\circ} 49^{\prime} 39^{\prime \prime} \mathrm{BT}$ dan titik selatan Masjidilharam berada pada titik koordinat $21^{\circ} 25^{\prime} 14^{\prime \prime} \mathrm{LU}, 39^{\circ} 4^{\prime}$ '32"BT. Dari dua titik koordinat Masjidilharan tersebut, masing-masing dihitung azimut arah geosentrik dari Kabupaten Gorontalo. ${ }^{24}$

1) Arah Geosentris Selatan

$$
\begin{aligned}
& \quad \operatorname{Tan} \mathrm{K}=\sin \left(123^{\circ} 03^{\prime} 37^{\prime \prime}-39^{\circ} 49^{\prime} 32^{\prime \prime}\right) /\left(\cos 00^{\circ} 32^{\prime} 17^{\prime \prime} \times \tan 21^{\circ}\right. \\
& \left.25^{\prime} 14^{\prime \prime}-\sin 00^{\circ} 32^{\prime} 17^{\prime \prime} \times \cos \left(123^{\circ} 03^{\prime} 37^{\prime \prime}-39^{\circ} 49^{\prime} 32^{\prime \prime}\right)\right) \\
& \text { Tan } \mathrm{K}=2,538528603 \\
& \mathrm{~K}=\operatorname{Tan}^{-1} 2,538528603 \\
& \mathrm{~K}=68^{\circ} 29^{\prime} 56,69^{\prime}
\end{aligned}
$$$$
\text { Azimut arah selatan }=360^{\circ}-68^{\circ} 29^{\prime} 56,69^{\prime \prime}=291^{\circ} 30^{\prime} 03,31^{\prime \prime} \text {. }
$$

2) Arah Geosentris Utara

$$
\begin{aligned}
& \operatorname{Tan} \mathrm{K}=\sin \left(123^{\circ} 03^{\prime} 37^{\prime}{ }^{\prime}-39^{\circ} 49^{\prime} 39^{\prime \prime}\right) /\left(\cos 00^{\circ} 32^{\prime} 17^{\prime \prime} \times \tan 21^{\circ}\right. \\
& \left.25^{\prime} 32^{\prime \prime}-\sin 00^{\circ} 32^{\prime} 17^{\prime} \times \cos \left(123^{\circ} 03^{\prime} 37^{\prime}{ }^{\prime}-39^{\circ} 49^{\prime} 39^{\prime \prime}\right)\right)
\end{aligned}
$$

${ }^{24}$ Ahmad Izzuddin, Akurasi Metode-Metode Penentuan Arah Kiblat (Jakarta: Kementerian Agama RI, 2012), 164. 
Tan $\mathrm{K}=2,537867155$

$\mathrm{K}=\operatorname{Tan}^{-1} 2,537867155$

$\mathrm{K}=68^{\circ} 29^{\prime} 38,36^{\prime \prime}$

Azimut arah utara $=360^{\circ}-68^{\circ} 29^{\prime} 38,36^{\prime \prime}=291^{\circ} 30^{\prime} 21,6^{\prime \prime}$.

Secara matematis, bila ada bangunan masjid di Kabupaten Gorontalo berada pada posisi azimut $291^{\circ} 30^{\prime} 03,31^{\prime \prime}$ sampai dengan azimut $291^{\circ} 30^{\prime} 21,6^{\prime \prime}$, maka arah masjid tersebut mengahadap Masjidilharam. Secara matematis, toleransi pelencengan arah kiblat sebuah masjid hanya terdapat pada toleransi kebolehan dalam memilih arah yang harus dihadap oleh sebuah masjid, antara arah Ka'bah, atau arah Masjidilharam, atau arah tanah haram yang telah diformulasikan sesuai arah Masjid Quba. Untuk Kabupaten Gorontalo, arah Ka'bah adalah 291³0’10,9", arah Masjidilharah adalah $291^{\circ} 30^{\prime}$ 03,31" sampai dengan azimut 291 30' 21,6", arah tanah haram yang diformulasikan sesuai dengan arah Masjid Quba adalah $291^{\circ}$ $05^{\prime} 47,21^{\prime \prime}$ sampai dengan $291^{\circ} 54^{\prime} 34,5^{\prime \prime}$.

\section{Toleransi secara Sosiologis}

Secara sosiologis, toleransi pelencengan arah kiblat selama tidak terlihat pergeseran arah saf dalam salat atau terlihat pergeseran badan orang yang salat. Menurut Thomas Djamaluddin, bila pelencengan arah kiblat di bawah 4 derajat busur belum terlihat pergeseran barisan saf salat atau pergeseran badan orang yang salat. Artinya, pergeseran badan orang yang salat dalam rentang di bawah 4 derajat ke kiri atau ke kanan saat salat belum terlihat dengan jelas secara kasat mata pergeseran badan orang yang salat. ${ }^{25}$ Bila dilihat secara sosilogis, dengan ukuran badan manusia diukur dari bahu kiri ke kanan sekitar 30 centimeter atau sekitar 300 milimeter. Bila ukuran badan manusia yang salat dianggap ukuran 300 milimater, maka dengan rumus koreksi pelencengan arah kiblat "panjang saf dikalikan Tangen selisih azimut kiblat dengan azimut bangunan" dapat diketahui berapa derajat

\footnotetext{
${ }^{25}$ Thomas Djamaluddin, "Tidak ada Perubahan Arah Kiblat," 17 Juli 2010 https://tdjamaluddin.wordpress.com/2010/07/17/tidak-ada-perubahan-arah-kiblat/.
} 
pergeseran badan orang salat baru bisa dilihat. 300 milimeter $\mathrm{x}$ Tan 6 derajat $=$ 31,53 milimeter atau sekitar 3 centimeter. Artinya, saat orang yang salat bergeser badannya ke kiri atau ke kanan sebesar 6 derajat, bentuk pergeseran badannya hanya 3 centimeter.

Sebagai ilustrasi pelencengan arah kiblat yang tidak dapat dihindari dan belum terlihat jelas bentuk pelencengan badan saat orang melaksanakan salat, diumpamakan sebidang sajadah dengan ukuran lebar 50 centimeter dan panjang 100 centimeter sebagaimana terlihat pada gambar nomor 2. Dari ukuran sajadah tersebut dapat juga diketahui besaran derajat sajadah dalam setiap centimeter yang ada di hadapar orang yang melakukan salat dari posisi tengah sajadah ke kiri atau ke kanan.

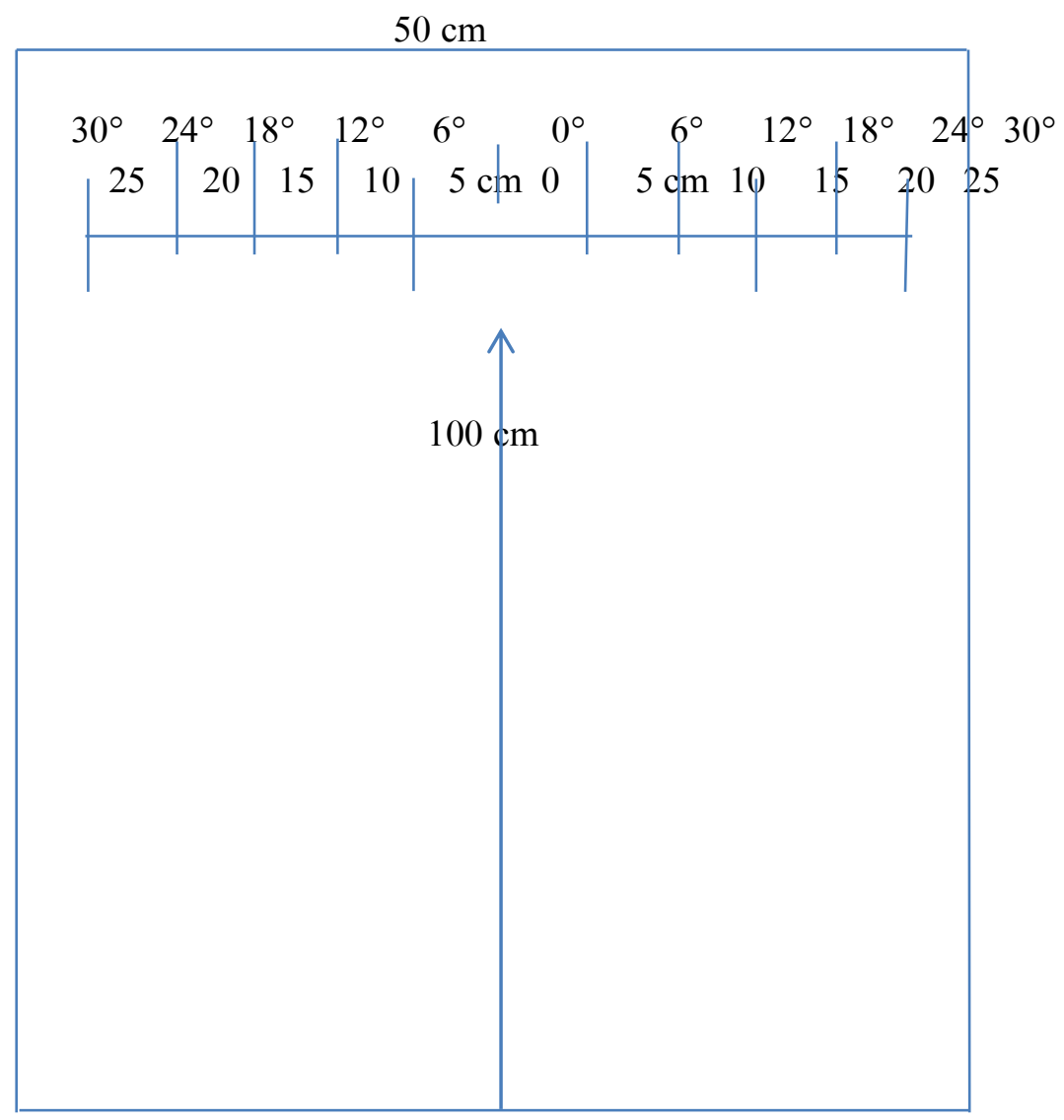

Gambar 2. Ilustrasi Sajadah Orang Salat

Untuk melihat besaran pelencengan yang terjadi saat orang melakukan salat dengan ukuran sajadah $50 \mathrm{~cm}$ x $100 \mathrm{~cm}$ adalah dengan menggunakan rumus koreksi 
pelencengan arah kiblat. $500 \mathrm{~mm} \times$ Tan $6^{\circ}=52,55 \mathrm{~mm}$. Penulis bulatkan menjadi 5 centimeter dalam setiap pergeseran 6 derajat busur. Dari gambar nomor 2 dapat disimpulkan bahwa setiap pergeseran 5 centimeter setara dengan pergeseran 6 derajat busur baik ke kiri atau ke kanan. Pergeseran 6 derajat busur atau sekitar 5 centimeter saat orang melakukan salat belum bisa terlihat jelas pergeseran arah badan orang yang salat dari arah sajadah yang diasumsikan pas posisi arah Ka'bah. Pergeseran badan orang yang salat sekitar 5 centimeter tersebut bisa terjadi dengan sebab tarikan nafas. Artinya, pergeseran 6 derajat dari arah kiblat ke kiri atau ke kanan saat melaksanakan salat tidak dapat dihindari dan ini bisa dijadikan standar toleransi pelencengan arah kiblat secara sosiologis, karena Allah tidak membebankan seorang hamba di luar kemampuarnya dalam menjalankan ibadah kepada Nya.

Korelasi antara toleransi pelencengan arah kiblat secara matematis dengan toleransi pelencengan arah kiblat secara sosiologis terdapat pada kesempurnaan ibadah salat seseorang. Arah bangunan masjid yang dibangun berdasarkan arah Ka'bah, atau arah Masjidilharam, atau arah tanah haram akan menjadi dasar pijakan garis saf masjid yang menjadi landasan arah kiblat orang yang salat. Bila bangunan masjid melenceng arah kiblat 6 derajat, maka orang yang salat akan melenceng badannya 12 derajat dari arah kiblat. Ketepatan arah bangunan masjid dengan arah kiblat akan menghasilkan kesempurnaan salat orang yang melaksanakan salat dalam masjid tersebut. Untuk konteks Indonesia saat ini, ada kekeliruan bila disimpulkan ada radikal dalam pengukuran arah kiblat dan akurasinya fleksibel sebagaimana kesimpulan penelitian ABD. Karim Faiz. Penyesuaian arah kiblat masjid secara matematis bukanlah sebuah sikap yang radikal dan akurasi arah kiblat masjid di Indonesia tidak fleksibel mengikuti pemahaman masyarakat tapi pengetahuan masyarakat tentang arah kiblat harus sesuai dengan perkembangan ilmu pengetahuan atronomi Islam atau ilmu falak. ${ }^{26}$

\footnotetext{
${ }^{26}$ Abd Karim Faiz, "Moderasi Fiqh Penentuan Arah Kiblat: Akurasi Yang Fleksibel,” JIL: Journal of Islamic Law 1, No. 1 (27 Februari 2020): 83-99, https://doi.org/10.24260/jil.v1i1.23.
} 
Ada tiga tahapan pengukuran arah kiblat yang harus dilakukan oleh panitia pembagunan masjid agar sebuah masjid benar-benar menghadap arah kiblat. (1) Pengukuran arah kiblat dilakukan pada saat hendak mendirikan bangunan masjid. Pengukuran ini bertujuan sebagai acuan dalam membangun masjid agar sesuai dengan arah kiblat. Kesalahan dalam pengukuran arah kiblat saat ini akan berakibat melenceng saf salat saat masjid telah selesai dibangun. (2) Pengukuran arah kiblat kembali dilakukan saat pondasi bangunan telah selesai dan tiang-tiang masjid telah ada. Pengukuran arah kiblat ini bertujuan untuk dijadikan pedoman dalam membuat dinding masjid, bila arah bangunan didapati melenceng dalam sekala kecil bisa diatasi dengan penyesuaian arah dinding masjid. (3) Pengukuran arah kiblat dilakukan saat bangunan telah selalesai dan hendak dibuat lantai. Pengukuran kali ini bertujuan agar lantai masjid yang di dalam nya ada garis saf salat bisa diposisikan benar-benar sesuai dengan arah kiblat. Bila dalam tiga tahapan ini ada pendampingan arah kiblat, maka bisa dipastikan masjid tersebut sesuai arah bangunannya dengan arah kiblat sesuai dengan hasil perhitungan ilmu falak.

\section{E. Kesimpulan}

Toleransi pelencengan arah kiblat di Indonesia terbagi dua macam dengan dua kegunaan. Toleransi secara matematis. Secara matematis, toleransi pelencengan arah kiblat dapat diambil dari kebolehan dalam menghadap kiblat selain arah Ka'bah bagi orang yang jauh dari Ka'bah, baik arah Masjidilharam atau arah tanah haram yang diformulasikan sesuai dengan arah Masjid Quba. Nilai toleransi arah kiblat secara matematis ini harus difungsikan pada toleransi pelencengan posisi arah bangunan masjid. Artinya, sebuah bangunan masjid masih dianggap tepat arah kiblat bila masih menghadap salah satu dari tiga arah tersebut. Secara ilmu falak dan ilmu arsitektur, sebuah bangunan masjid, sebesar apapun bangunan nya, masih bisa dibangun kemanapun arah yang diinginkan.

Toleransi secara sosiologis. Secara sosiologis, toleransi pelencengan arah kiblat dapat dipedomani pada kemampuan seseorang dalam menghadap kiblat saat melaksanakan salat. Setiap orang yang melaksanakan salat tidak mampu tetap 
badannya di bawah dari 6 derajat baik ke kiri atau ke kanan mulai dari awal salat sampai dengan selesai. Toleransi pelencengan 6 derajat secara sosiologis harus diposisikan pada toleransi posisi arah badan seseorang saat melaksakan salat, bukan arah bangunan masjid. Artinya, bila seseorang bergeser badannya dalam melaksanakan salat di atas 6 derajat ke kiri atau ke kanan, maka orang tersebut dianggap sudah berpaling dari arah kiblat dalam melaksanakan salat.

\section{Daftar Pustaka}

Abu Sabda. Ilmu Falak, Rumusan Syar'i dan Astronomi. Waktu Shalat dan Arah Kiblat. 1. Bandung: Persis Pers, 2019.

Ahmad Izzuddin. Akurasi Metode-metode Penentuan Arah Kiblat. Jakarta: Kementerian Agama RI, 2012.

Alfirdaus Putra. Cepat \& Tepat Arah Kiblat. Yogyakarta: Elmatera, 2015.

Arifin, Zainul. "Toleransi Penyimpangan Pengukuran Arah Kiblat." ELFALAKY 2, No. 1 (13 Juni 2018). https://doi.org/10.24252/ifk.v2i1.14159.

Budiwati, Anisah. "Akurasi Arah Kiblat Masjid di Ruang Publik." JSSH (Jurnal Sains Sosial dan Humaniora) 2, No. 1 (2018).

Faiz, Abd Karim. "Moderasi Fiqh Penentuan Arah Kiblat: Akurasi Yang Fleksibel." JIL: Journal of Islamic Law 1, No. 1 (27 Februari 2020), https://doi.org/10.24260/jil.v1i1.23.

Isa, Teungku Mustafa Muhammad. Fiqih Falakiyah. Yogyakarta: Deepublish, 2016.

Ismail, Ismail. "Standar Operasional Prosedur (SOP) Kalibrasi Arah Kiblat Masjid Di Era Digital." Al-Marshad: Jurnal Astronomi Islam Dan Ilmu-Ilmu Berkaitan 5, No. 1 (2 Juni 2019). https://doi.org/10.30596/jam.v5i1.3126.

- "Urgensi Dan Legitimasi Fatwa Majelis Permusyawaratan Ulama Aceh Nomor 3 Tahun 2018 Tentang Penetapan Arah Kiblat." Al-Manahij: Jurnal Kajian Hukum Islam 14, No. 1 (2 Juni 2020), https://doi.org/ 10.24090/mnh.v14i1.3669. 
Izzuddin, Ahmad. "Typology Jihatul Ka'bah on Qibla Direction of Mosques in Semarang." Ulul Albab: Jurnal Studi Dan Penelitian Hukum Islam 4, No. 1 (1 November 2020), https://doi.org/10.30659/jua.v4i1.12186.

Jalil, Abdul, dan Hosen Hosen. “Qibla Jurisprudence: Deviation of Mosques' Qibla in Pamekasan Madura." Islamuna: Jurnal Studi Islam 7, No. 2 (21 Desember 2020), https://doi.org/10.19105/islamuna.v7i2.3381.

Kementerian Agama RI. Ephemeris Hisab Rukyat, 2020.

MPU Aceh. "Fatwa Majelis Permusyawaratan Ulama Aceh Nomor 3 Tahun 2018 Tentang Penetapan Arah Kiblat," 2018. https://ppid2.acehprov.go.id/ v2/dip/view/1430.

Muh. Ma'rufin Sudibyo. Sang Nabi Pun Berputar, Arah kiblat dan tata cara pengukurannya. Solo: Tinta Medina, 2011.

Muthmainnah, Muthmainnah, dan Fattah Setiawan Santoso. "Pemanfaatan Sains Dan Teknologi Dalam Pengukuran Arah Kiblat Di Indonesia." Ulumuddin : Jurnal Ilmu-Ilmu Keislaman 10, No. 2 (29 Desember 2020), https://doi.org/10.47200/ulumuddin.v10i2.441.

Nafi', Agus Yusrun. "Verifikasi Fatwa MUI Nomor 03 Tahun 2010 Tentang Arah Kiblat." Mahkamah : Jurnal Kajian Hukum Islam 9, No. 1 (26 Februari 2016). https://doi.org/10.24235/mahkamah.v9i1.289.

Rahmatiah H. "Pengaruh Human Eror Terhadap Akurasi Arah Kiblat Masjid Dan Kuburan Di Kabupaten Gowa Provinsi Sulawesi Selatan." ELFALAKY 4, No. 2 (13 Desember 2020). https://doi.org/10.24252/ifk.v4i2.18069.

Slamet Hambali. Ilmu Falak, Arah Kiblat Setiap Saat. Yogyakarta: Pustaka Ilmu, 2013.

Slamet Hw. Dasar-dasar Ilmu Ukur Segitiga Bola: Menentukan Arah Kiblat, Waktu Sholat, Awal Bulan Qamariah, dan Gerhana. Jawa Tengah: Muhammadiyah University Pres, 2018.

Thomas Djamaluddin. "Tidak ada Perubahan Arah Kiblat," 17 Juli 2010. https://tdjamaluddin.wordpress.com/2010/07/17/tidak-ada-perubahan-arahkiblat/. 